\title{
Diversification strategies in the pesticide industry: from seeds to biopesticides
}

\author{
Victor Pelaez ${ }^{1}$ Gabriel Mizukawa ${ }^{2}$
}

${ }^{1}$ Departamento de Economia, Universidade Federal do Paraná (UFPR), 80210-170, Curitiba, PR, Brasil. E-mail: victor@ufpr.br. Corresponding author.

${ }^{2}$ Curso de Ciências Econômicas, Universidade Federal do Paraná (UFPR), Curitiba, PR, Brasil.

ABSTRACT: The pesticide industry has undergone a diversification process led by six leading companies (Monsanto, Syngenta, Bayer, Dow, DuPont, BASF) that control roughly 68\% of the world market. This growth, initiated in the second half of the 1990 s, occurred through deals and acquisitions of companies from the seed and biopesticide markets. This paper analyzes these diversification strategies, which have involved a capital mobilization process based on the exploitation of economies of scope and management of complementary assets. This aims to minimize the risks of investment in consolidated markets as well as in new ones.

Key words: pesticides, seeds, biopesticides, diversification, growth.

Estratégias de diversificação na indústria de agrotóxicos: de sementes a biopesticidas

RESUMO: A indústria de agrotóxicos tem passado por um processo de diversificação, desencadeado pelas seis empresas líderes (Monsanto, Syngenta, Bayer, Dow, Dupont, BASF), que detêm cerca de $68 \%$ das vendas mundiais de agrotóxicos. Esse crescimento, iniciado na segunda metade do ano de 1990, tem ocorrido por meio de aquisições e acordos que envolvem empresas do ramo de sementes e do segmento de biopesticidas. Este artigo analisa essas estratégias de diversificação nas quais constata-se um processo de mobilização de capitais, baseado na exploração de economias de escopo e na gestão de ativos complementares. Isto permite minimizar o risco de investimentos, tanto em mercados já consolidados quanto em novas áreas de atuação.

Palavras-chave: agrotóxicos, sementes, biopesticidas, diversificação, crescimento.

\section{INTRODUCTION}

The chemical pesticides industry achieved worldwide sales of approximately US\$61 billion in 2013, a 140\% increase compared to 2000 (PELAEZ et al., 2015). Worldwide sales of organic pesticides (biopesticides) have been estimated at US\$2.4 billion, with a $15 \%$ average annual growth rate in this decade (FRABOTTA, 2014). Meanwhile, the world seed market was estimated at US\$45 billion in 2012 , with a growth rate of around $80 \%$ since 2005 (RAGONNAUD, 2013). In addition to steep growth rates, these three markets share the predominant participation of six companies from the chemical and pharmaceutical industries (Syngenta, Bayer, DuPont, Dow, BASF, and Monsanto). The purpose of the present article is to analyze the diversification strategies of these companies: from chemical pesticides to the seeds and biopesticides segments.

These strategies occur through capital mobilization, mainly through acquisitions and cooperation agreements that in turn allow the resources necessary for the viability of a new productive activity and/or technological innovation to be assimilated and recombined. Herein we analyze the external growth of leading agrochemical industry companies from the theoretical perspective of Edith PENROSE (2009) based on the boundaries of the growth of the firm. In this approach, the growth logic is guided by the technological basis of the company - the set of productive activities (machinery, processes, skills, raw materials) that define its core competencies. Thus, risk management of operations in new markets would be linked to what the author calls "specialization 
within broad limits", meaning that companies seek to identify new productive opportunities in markets wherein their core of competencies guarantees their competitiveness. New assets, acquired through acquisitions or agreements, tend to complement the core competencies. Knowledge acquired and/ or shared with other companies corresponds to what TEECE (1986) calls as a strategy for the management of complementary assets for the technological innovation process. Asset management - involving activities such as marketing, distribution networks, and technical assistance - establishes the conditions for the innovating company to appropriate its competencies within a competitive environment and a context of inter-capitalist cooperation. Cooperation is understood here as the result of investment risk-reducing strategies, via capital association, and/or a means to gain faster access to knowledge associated with new branches of activity (TIDD et al., 2005). Asset management also allows the exploitation of economies of scope, since the company's assets, associated with its technological and commercial competencies, can be used or transferred to different markets (TEECE, 1980).

\section{MATERIALS AND METHODS}

The pesticide industry is defined herein according to the provisions of subparagraph I (a) of Art. 2, Law 7.802/89, which considers pesticides "products of physical, chemical or biological processes (...) whose purpose is to change the composition of flora and fauna, in order to prevent the damaging action of harmful living beings." Thus, the segmentation of the market is based on the process for obtaining products. Two segments are considered the most relevant: chemical pesticides and biological pesticides, designated "chemicals" or "biopesticides" hereafter, respectively. The seed market revenue data, and the information on acquisitions and agreements made by the leading companies in the agrochemical industry -including the chemical and biopesticide segments and the seed industry - were obtained from their financial reports, as well as from the field of activity-specialized journals (Agropages, Agrow and Farm Chemicals International-FCI). These journals report investments and commercial transactions made by agrochemical and seed companies worldwide, and the evolution of their regulatory environment.

\section{RESULTS AND DISCUSSION}

In a highly concentrated industry, the six largest pesticide companies (Syngenta,
Bayer, BASF, Dow, Monsanto, and DuPont) control approximately $68 \%$ of worldwide sales. These companies constitute an oligopolistic core, distinguished by their high capacity for research and development (R\&D) of new pesticide molecules. The main barrier to entry to this core is the high R\&D investment capacity, which allows a portfolio of patentable active ingredients (AIs) to be obtained. The predominant form of competition within this oligopolistic core is quality - the result of a combination of new patented AIs and brand valorization. All other companies are located in a competitive fringe, wherein the innovative capacity is linked to the development of synthetic processes for products with expired patents (equivalent to the reference, or "generic"). The main form of competition within this fringe is through pricing, since it is a specialized segment of products with expired patents (PELAEZ et al., 2015).

The six largest agrochemical companies went through a process of diversification through acquisitions and agreements starting in the mid-1990s, focused on R\&D and production of genetically modified (GM) seeds. Monsanto pioneered this research, investing in the development of broad spectrum, glyphosatebased herbicide (Roundup)-resistant GM soybeans between 1980 and 1990. The development of this technology reveals an innovation strategy based on the management of complementary assets (seeds and herbicides) through which Monsanto expanded the scope of application of its initial technological basis - which was based on agronomic experimentation and chemical synthesis - by adding genetic engineering skills.

With the approval of GM soy by several national regulatory agencies, Monsanto began a worldwide process of acquiring 51 seed companies between 1996 and 2014. This growth strategy was followed by other leading companies, which acquired seed companies in several countries, as follows: Dow: 28, Syngenta: 28, Bayer: 21, DuPont: 17, BASF: 3 (Table 1). For these companies, the development of varieties resistant to their herbicides (glufosinate, 2,4-D, dicamba, paraquat, imidazolinones) grants the possibility of selling technological packages able to extend their chemicals' life cycles. Companies also started developing insect- and water stress-resistant GM crops; new generations of plants that combine these characteristics have been subsequently developed. The combination of assets associated with the production and trade of seeds and pesticides reveals 
Table 1 - Acquisitions and agreements in the pesticide, seeds, and biopesticides markets.

\begin{tabular}{|c|c|c|c|c|c|c|c|c|}
\hline \multirow{2}{*}{ Company } & \multicolumn{4}{|c|}{----------------Acquisitions (1996-2015)----------------- } & \multicolumn{4}{|c|}{------------------Agreements (2000-2015)------------- } \\
\hline & Pesticides & Seeds & Biopesticides & Total & Pesticides & Seeds & Biopesticides & Total \\
\hline Monsanto & 0 & 51 & 2 & 53 & 25 & 39 & 7 & 71 \\
\hline Bayer & 12 & & 4 & 37 & 43 & 34 & 6 & 83 \\
\hline Dow & 7 & 28 & 0 & 35 & 25 & 25 & 2 & 52 \\
\hline Syngenta & 4 & 28 & 3 & 35 & 41 & 31 & 8 & 80 \\
\hline DuPont & 4 & 17 & 1 & 22 & 21 & 19 & 2 & 42 \\
\hline BASF & 8 & 3 & 1 & 12 & 33 & 42 & 3 & 78 \\
\hline Total & 35 & 148 & 11 & 194 & 163 & 151 & 21 & 406 \\
\hline
\end{tabular}

Source: The authors' own elaboration based on articles from Agrow.

a growth and competition strategy based on the exploitation of economies of scope - investments in $\mathrm{R} \& \mathrm{D}$, distribution, and technical assistance competencies and infrastructures can be combined and utilized in both markets.

Figure 1 shows the sales evolution of the seeds branches of these companies. Monsanto and DuPont are noteworthy, with growth rates of approximately $700 \%$ and $400 \%$, respectively. DuPont's main acquisition in the seed industry occurred in 1999 (Pioneer Hi-Bred) for a value of US\$7.7 billion (AGROW, 1999). Currently, Monsanto is predominantly a seed company, as $70 \%$ of its turnover comes from the seed segment, with the remaining 30\% from agrochemicals (MONSANTO, 2015). The same proportion is seen in DuPont's Agricultural Products Division (DUPONT, 2015).

In addition to acquisitions, the agreements in the seed sector ( 151 between 2000 and 2015) revealed an external growth strategy in which asset sharing $(\mathrm{R} \& \mathrm{D}$, production, and distribution) with other companies allows the risks of capital mobility to be reduced (TEECE, 1986; HAGEDOORN, 1993). In this aspect, BASF differed from the remaining companies in having opted for this growth strategy. The company signed the largest number of agreements with seed industry companies (42), and acquired the fewest companies in this segment (3) (Table 1), focusing on plant genomics research. Among the agreements signed by BASF, the partnership with Monsanto in 2007 is noteworthy, amounting to US\$1.5 billion for the development of GM soybean, corn, cotton, and canola varieties (MONSANTO, 2007). BASF has not yet reported sales results for its seed branch, as indicated in Figure 1. Although the first variety of GM soybean from BASF was approved in Brazil in 2010, as a result of a cooperation agreement between BASF and the Brazilian Agricultural Research Corporation (Embrapa), authorization for its use in Europe was only granted in 2015 (EMBRAPA, 2015; BASF, 2014).

Since the 2000s, another movement of company diversification involving the biopesticides segment has become apparent. These products differ from pesticides in their constitution: their AIs come from natural sources (mostly living beings). The North American Environmental Protection Agency (EPA) divides biopesticides into three classes: microbial pesticides, whose AIs consist of microorganisms; biochemical pesticides, substances found in nature that act through non-toxic mechanisms; and plant-incorporated protectants (PIPs), pesticides produced by plants themselves as a result of gene implantation (EPA, 2015a). RNA interference (RNAi), capable of inhibiting gene expression in living organisms, is a more recent example of a PIP that has generated $R \& D$ acquisitions and agreements for the companies analyzed herein. In this decade, Monsanto, Syngenta, Dow, and DuPont had seven R\&D agreements involving RNAi with biotechnology enterprises (Preceres, Novozymes, Marina Biotech, Alnylam, Plant Response Biotech, Radiant Genomics, and Caribou).

Advantages attributed to biopesticide usage over chemically synthesized products are related to the fact that biopesticides: are supposedly less toxic; are more selective in combating unwanted biological targets; possess higher efficiency at lower concentrations; decompose more quickly, reducing adverse environmental effects; and can be used in 


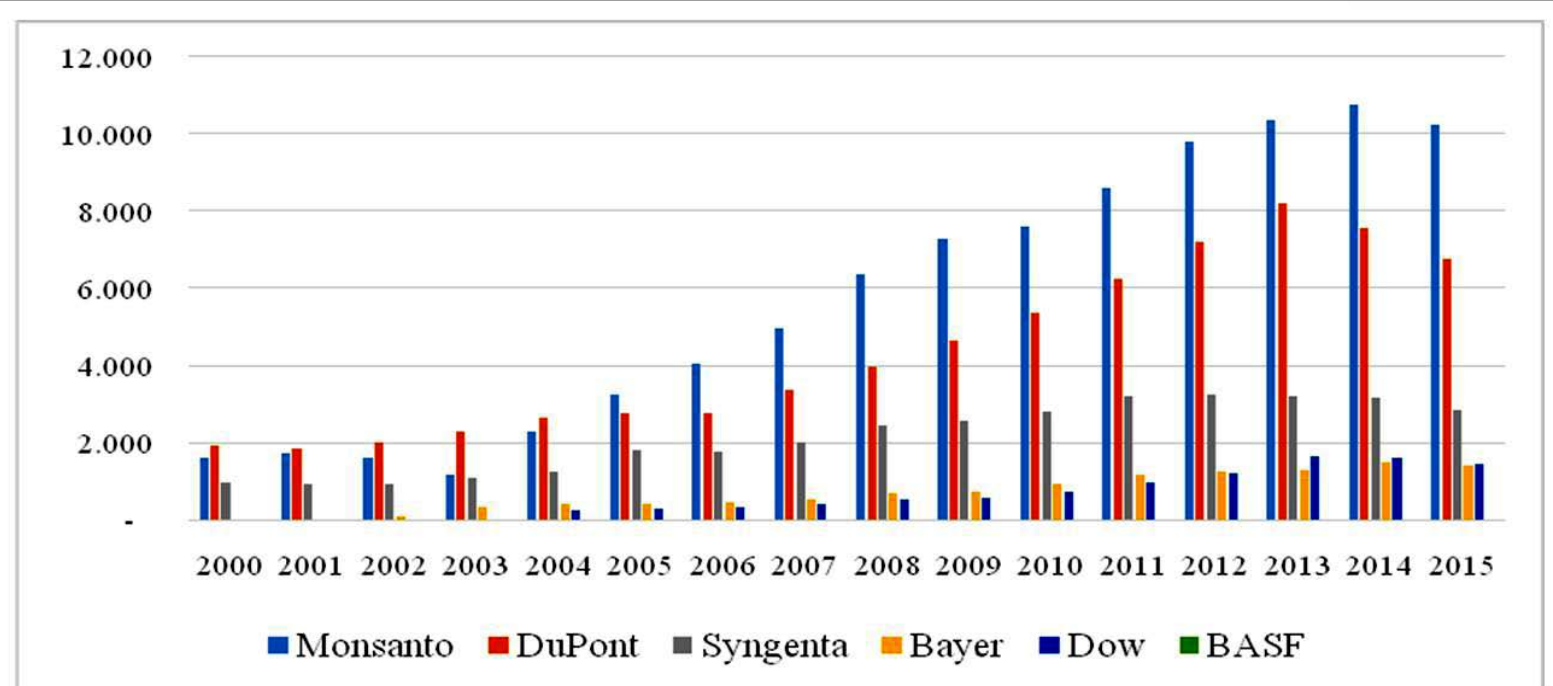

Source: The authors' own elaboration based on companies' annual reports (2000-2015).

Figure 1 - Seed sales by the leading pesticide companies (US\$ million).

integrated pest management, reducing the use of conventional pesticides (ALEXANDER, 2016). By September 2015, 436 biopesticide AIs and 1401 derivatives had already been registered in the United States (EPA, 2015a).

The beginning of the diversification process from chemicals to biopesticides in the leading companies can be traced to the first agreements between Bayer and Syngenta in the mid-2000s. Agreements multiplied from the beginning of this decade, in terms of both R\&D and partnerships for biopesticide distribution in national and regional markets (Table 2). One of the most important agreements took place in 2013 between Monsanto and the Danish company Novozymes. With a disclosed amount of US\$300 million, the agreement gave rise to the BioAg Alliance, involving research activities from both companies for the production and marketing of microbial biopesticides (MONSANTO, 2013).

Such agreements were followed by the acquisition of 10 biopesticide companies between 2012 and 2015 by pesticide industry leaders for an approximate amount of US\$2.4 billion: BASF acquired Becker Underwood, Bayer acquired AgraQuest, Prophyta, and Biagro, Monsanto acquired Beeologics, Agradis, and Rosetta Green, Syngenta acquired Devgen and Pasteuria, and DuPont acquired Taxon
Biosciences. The largest of these acquisitions was BASF's purchase of the American company Becker Underwood, worth US\$1.02 billion in 2012 (BASF, 2012).

The growing demand for less toxic agricultural products and the regulatory pressure on the use of chemical pesticides stand out among the causes for these companies' diversification into the biopesticides sector. There are two aspects to consider on the first issue: consumer demands and farmer demands. The increased demand for healthier, chemical-free food led to an increase in organic product consumption, especially in countries with higher per capita income. Allied to this, the biopesticides portfolio is increasing, and its diffusion is directly linked to a learning process that takes place among both the offering companies (learning by doing) and users, by incorporating new handling techniques (learning by using). The diffusion benefited from the inclusion of large chemical companies in the biopesticides segment, as their brands and distribution networks has contributed to greater product acceptance among farmers (FRABOTTA, 2014). The regulatory pressure exerted a direct impact on the increased development costs of new chemical AIs - approximately $70 \%$ between 1995 and 2005, from US\$152 million to US\$256 million. Approximately $60 \%$ of these costs are 
Table 2 - Agreements made in the biopesticides segment.

\begin{tabular}{|c|c|c|c|c|}
\hline Year & Company 1 & Company 2 & Type of Agreement & Specialty \\
\hline 2003 & Bayer & EBS & Sale & Microbial \\
\hline 2005 & Syngenta & HBERC & $\mathrm{R} \& \mathrm{D}$ & Biochemical \\
\hline 2006 & Bayer & Magellan & R\&D & Microbial \\
\hline \multirow{2}{*}{2009} & BASF & AgraQuest & Sale & Microbial \\
\hline & Bayer & AgraQuest & Sale & Microbial \\
\hline \multirow{2}{*}{2010} & Monsanto & AgraQuest & $\mathrm{R} \& \mathrm{D}$ & Microbial \\
\hline & BASF & Embrapa & $\mathrm{R} \& \mathrm{D}$ & Microbial \\
\hline \multirow{6}{*}{2011} & Syngenta & Pasteuria & $\mathrm{R} \& \mathrm{D}$ & Microbial \\
\hline & Syngenta & Pasteuria & Sales & Microbial \\
\hline & BASF & INTA & $\mathrm{R} \& \mathrm{D}$ & Biochemical \\
\hline & Bayer & AgraQuest & Expansion; Sale & Microbial \\
\hline & DuPont & AgraQuest & Sale & Microbial \\
\hline & Syngenta & Marrone & Sale & Microbial \\
\hline \multirow{4}{*}{2012} & Monsanto & Marina Biotech & $\mathrm{R} \& \mathrm{D}$ & PIP (RNAi) \\
\hline & Monsanto & Alnylam & $\mathrm{R} \& \mathrm{D}$ & PIP (RNAi) \\
\hline & Syngenta & Novozymes & Sale & Microbial \\
\hline & Syngenta & Devgen & $\mathrm{R} \& \mathrm{D}$ & PIP (RNAi) \\
\hline \multirow{2}{*}{2013} & Syngenta & Stockton & Sale & Biochemical \\
\hline & Monsanto & Novozymes & R\&D; Sale & PIP (RNAi) \\
\hline \multirow{4}{*}{2014} & Bayer & Bion & Sale & Microbial \\
\hline & Bayer & GreenLight & $\mathrm{R} \& \mathrm{D}$ & Microbial \\
\hline & Syngenta & AgBiome & $\mathrm{R} \& \mathrm{D}$ & Microbial \\
\hline & Monsanto & Preceres & $\mathrm{R} \& \mathrm{D}$ & PIP (RNAi) \\
\hline \multirow{5}{*}{2015} & Dow & Radiant Genomics & $\mathrm{R} \& \mathrm{D}$ & PIP (RNAi) \\
\hline & Dow & Synthace & $\mathrm{R} \& \mathrm{D}$ & Microbial \\
\hline & DuPont & Caribou & $\mathrm{R} \& \mathrm{D}$ & PIP (RNAi) \\
\hline & Syngenta & DSM & $\mathrm{R} \& \mathrm{D}$ & Microbial \\
\hline & Monsanto & PlantResponse & Expansion & $\begin{array}{l}\text { Microbial; } \\
\text { Biochemical }\end{array}$ \\
\hline
\end{tabular}

Source: The authors' own elaboration from companies' annual reports and Agropages.

related to field-testing, environmental chemistry, and human toxicology whose results must meet the regulatory bodies' reference standards (PHILLIPS MCDOUGALL, 2010).

Two recent events have contributed to the intensification of regulatory pressures on the chemical pesticides segment. The first was the entry into force in 2001 of Regulation 1107/09 of the European Union (EU), which imposed stricter rules for market release of pesticides. These rules concentrate on risk analysis, i.e. products with carcinogenic or teratogenic effects, or endocrine regulators, are now prohibited, regardless of dosage. Preliminary assessments promoted by the European Commission identified 57 AIs - with hundreds of products based on those substances - that can be banned from the EU market based on that regulation (EC, 2006). The second event concerns the findings of the toxic effect of neonicotinoids on bees, which led to a restriction of use of three AIs in the EU in 2013 (EC, 2013). Five neonicotinoid AIs are expected to be prohibited in the United States in 2016 (EPA, 2015b). 
These causes act synergistically in which changes in food consumption patterns have an interdependent relationship with the evolution of national regulatory frameworks. In this context, the leading agrochemical companies have been identifying productive opportunities to adapt to the institutional transformations of their operating environment. This adaptation involves both acquisition and recombination of their productive resources to manage the risk of investment in new segments and industries. The development of GM seeds promises a more rational use of chemicals in agriculture, including the reduction of insecticide usage on insectresistant seeds (FERNANDEZ-CORNEJO et al., 2014). Conversely, herbicide-resistant GM seeds stimulate their consumption, since the created technological package favors the continuity of its implementation (PELAEZ \& FUCK, 2014). The use of biopesticides is predominantly associated with a technological trajectory dedicated to integrated pest control, in which chemical and biological pesticides are complementarily employed (MEISTER MEDIA, 2011).

\section{CONCLUSION}

Agrochemical industry-leading companies' capital mobilization to the seed industry andt he biopesticides segment confirms a logic of external growth based on a "specialization within broad limits", as advocated by Penrose. By acting concurrently in these markets, companies exploit economies of scope generated by the production and marketing of technological packages involving pesticides (chemical and biological) and GM seeds.

In this diversification strategy, the companies' technological base (chemical synthesis) is expanded to incorporate biological synthesis processes, either via traditional methods (fermentation) or via genetic manipulation. In this case, a complementary asset management strategy is observed, as biological processes tend to complement the existing technological base in order to extend the life cycle of chemical products. Furthermore, the ways in which these assets can be managed will reduce the risk of investments in new areas - occurring through acquisitions and cooperation agreements with smaller companies specialized in the areas of interest, and with competitors in the original market (chemicals). The synergistic effect of this knowledge enables the adaptation of businesses to new institutional arrangements (regulation, consumption patterns), while maintaining or expanding their competitive advantages.

\section{REFERENCES}

AGROW. DuPont to acquire Pioneer for $\$ 7.7$ billion. Agrow, Mar. 26, 1999. Online. Available from: <http://bit.ly/1IPwyGJ>. Accessed: Feb. 24, 2015.

ALEXANDER, L. Biopesticides by the numbers. In: Biopesticides primed for growth: special report. Willougby: Meister Media, 2014. 24 p. Online. Available from: <http://bit. ly/2exnP1g>. Accessed: Oct. 27, 2016.

BASF. BASF and Embrapa launch Cultivance ${ }^{\circledR}$, August 25, 2015. Online. Available from: $<$ http://bit.ly/2eTiEFN $>$. Accessed: Dec. 12, 2015

BASF Report 2014. Online. Available from: <http:/ on.basf.com/1jq4hKE>. Accessed: Feb. 24, 2015.

BASF completes acquisition of Becker Underwood. BASF Newsroom, November 28, 2012. Online. Available from: $<$ http:// bit.ly/2eHFYJY>. Accessed: Dec. 02, 2015.

DUPONT. Data Book 2014. Online. Available from: $<$ http://bit. ly/1GhcSKN>. Accessed: Oct. 16, 2015.

EC (EUROPEAN COMMISSION). Priority list. ANNEX 1. Candidate list of 553 substances, December 30, 2006. Online. Available from: $<$ http://bit.ly/1ZMQluK $>$. Accessed: May 05, 2014.

. Bee health: EU-wide restrictions on pesticide use to enter into force on 1 December. May 24, 2013. Online. Available from: $<$ http://bit.ly/1PIYHyK>. Accessed: Dec. 12, 2015.

EMBRAPA.União Europeia aprova soja Cultivance ${ }^{\circledR}$ desenvolvida por Embrapa e BASF. Notícias, 23 jun. 2015. Online. Available from: <http://bit.ly/2eSKjYE $>$. Accessed: Dec. 11, 2015.

EPA (ENVIRONMENTAL PROTECTION AGENCY). What are biopesticides? Online. Available from: <http://1.usa. gov/1iMPXJ>j. Accessed: Sept. 25, 2015a.

EPA actions to protect pollinators. Online. Available from: $<$ http://bit.ly/1n36bmR>. Accessed: Dec. 12, 2015 b.

Integrated pest management principles. Online. Available from: $<$ http://1.usa.gov/1ij5o6A>. Accessed: July 02, 2015.

FERNANDEZ-CORNEJO, J. et al. Genetically engineered crops in the United States. United States: Department of Agriculture, 2014. 60p. (Economic Research Report, n. 64).

FRABOTTA, D. Stricter MRLs: pushing global demand for biopesticides. Farm Chemicals International, v.28, n.28, p. 18,2014 .

HAGEDOORN, J. Understanding the rationale of strategic technology partnering: interorganizational modes and sectoral differences. Strategic Management Journal, v. 14, p.371-385, 
1993. Available from: <http://onlinelibrary.wiley.com/doi/10.1002/ smj.4250140505/epdf>. Accessed: Jan. 23, 2016. doi: 10.1002/ smj.4250140505.

MEISTER MEDIA. Efficacy drives acceptance in IPM. Special report: the rise of biopesticides, 2011. 24p. Online. Available from: $<$ http://bit.ly/1mAkEGU>. Accessed: Dec. 19, 2015.

MONSANTO. 2014 Form 10-K. Online. Available from: $<$ http:// monsanto.info/1GkAzL3>. Accessed: Feb. 24, 2015.

Monsanto and Novozymes team up to provide sustainable bioagricultural solutions. Monsanto Newsroom, December 10, 2013. Online. Available from: <http://monsanto. info/1IPwPcI > . Accessed: Nov. 22, 2015.

BASF and Monsanto announce $R \& D$ and commercialization collaboration agreement in plant biotechnology. Monsanto Newsroom, March 21, 2007. Online. Available from: <http://monsanto.info/1OLOOgn $>$. Accessed: Nov. 22, 2015.

PELAEZ, V. et al. A (des)coordenação de políticas para a indústria de agrotóxicos no Brasil. Revista Brasileira de Inovação, v. 14, n. esp., p.153-178, 2015.

PELAEZ, V.; FUCK, M.P. Custos de produção de commodities nos EUA. Revista de Política Agrícola, v.XXIII, n.3, p.65-80, 2014.
PENROSE, E. The theory of the growth of the firm. Oxford: Oxford U.P., 2009. 249 p.

PHILLIPS MCDOUGALL. The cost of new agrochemical product discovery, development \& registration and research \& development predictions for the future. United Kingdom, 2010. 22p.

RAGONNAUD, G. The EU seed and plant reproductive material market in perspective: a focus on companies and market shares. European Union: Directorate-General for Internal Policies, 2013. 36p.

TEECE, D.J. Economies of scope, and the scope of the enterprise. Journal of Economic Behavior and Organization, v.1, p.223247, 1980. Available from: <http://www.sciencedirect.com/ science/article/pii/0167268180900025>. Accessed: Jul. 15, 2016. doi: 10.1016/0167-2681(80)90002-5.

Profiting from technological innovation: implications for integration, collaboration, licensing and public policy. Research Policy, v.15, p.285-305, 1986. Available from: <http:// www.sciencedirect.com/science/article/pii/0048733386900272>. Accessed: May 14, 2006. doi: 10.1016/0048-7333(86)90027-2.

TIDD, J. et al. Managing innovation: integrating technological, market and organizational change. West Sussex: John Wiley \& Sons, 2005. 582p. 